\title{
Research Paper Economic analysis of arrival and price behaviour of rose and gerbera flowers in Gultekhadi market Pune
}

See end of the paper for authors' affiliations

Correspondence to : V. B. GHOLAP

Department of AgriBusiness Management, Padmashree Dr. D.Y. Patil College of Agriculture Business Management, Akurdi, PUNE (M.S.) INDIA

Paper History : Received : 17.06.2016; Revised : 08.07.2016; Accepted : 09.08.2016
AbSTRACT : In India, floriculture is emerging as an important commercial crop. A lot of importance has been given to this sector due to its multiple uses, satisfying the aesthetic needs of the people, creating more employment, ensuring higher rate of returns to rural people and facilitating earning more foreign exchange. More specifically, they are being used as raw materials in the manufacture of essence, perfumes, medicines and confectioneries for direct consumption by the society. Agriculture supply is uncertain and this uncertainty in supply leads to fluctuations in prices. The broad objective of study was to examine price behaviour of major flowers in Pune. The data on arrivals and prices of flower crop under study for the period of 10 years i.e. from 2005-14 were used. The data were collected from the records of Gultekhadi market Pune. The results indicated that annual growth trend was maximum during $2011-12$ in areas and production of loose flowers. Annual growth trend was maximum during $2009-10$ in production of cut flowers. The study indicated positive percentage change in prices of gerbera $(+15.25 \%)$ and negative in prices of roses $(-22.83)$. Maximum negative percentage change was observed in case of arrivals of gerbera. Trends in arrivals and prices of rose in gultekhadi market shows decreasing trends from year 2005 to 2014. In case of gerbera decreasing trends was observed in arrivals and increasing trends in prices. Co-efficient of variation of real prices was found to be lowest in gerbera.

KEY Words : Arrival, Price, Behaviour of rose, Gerbera flowers

How To Cite This PAPer : Gholap, V.B., Benke, S.R. and Gade, P.V. (2016). Economic analysis of arrival and price behaviour of rose and gerbera flowers in Gultekhadi market Pune. Internat. Res. J. Agric. Eco. \& Stat., 7 (2) : 149-152, DOI : 10.15740/HAS/IRJAES/7.2/149-152. 